\title{
Nonpeptidic $\delta$-opioid Receptor Agonists Reduce Immobility in the Forced Swim Assay in Rats
}

Daniel C. Broom, Emily M. Jutkiewicz, John E. Folk, Ph.D., John R. Traynor, Ph.D., Kenner C. Rice, Ph.D., and James H. Woods, Ph.D.

The present study examined the effect of opioid receptor agonists in the rat forced swim assay. The $\delta$-opioid receptor agonists SNC80 $((+)-4-[(\alpha R)-\alpha-((2 S, 5 R)-4-A l l y l-2,5-$ dimethyl-1-piperazinyl)-3-methoxybenzyl]-N,Ndiethylbenzamide) and $(+) B W 373 U 86\left((+)-\left[1\left(S^{*}\right), 2 \alpha, 5 \beta\right]-\right.$ 4-[[2,5-dimethyl-4-(2-propenyl)-1-piperazinyl] (3-hydroxyphenyl)methyll-N,N-diethyl-benzamide dihydrochloride) produced a decrease in immobility indicating an antidepressant-like effect. At antinociceptive doses, neither the $\kappa$-opioid selective agonist CI977 (5R$(5 \alpha, 7 \alpha, 8 \beta)-N-m e t h y l-N-[7-(1-p y r r o l i d i n y l-1-$ oxaspiro[4,5]dec-8-yl]-4-benzofuranacetamide) showed a change in immobility that was identifiable by dose, nor were changes in immobility seen with morphine. A $\delta$-opioid mechanism of action in the forced swim assay was likely since naltrindole prevented the effects of both $\delta$-agonists. When compared to desipramine and fluoxetine, SNC80 was more active with a single dose whereas both desipramine and fluoxetine produced greater effects with subchronic dosing (3 doses). All three compounds were active when administered before the initial swim exposure. SNC80 was, however, more effective following a single dose than by subchronic administration demonstrating both a fast onset of activity and potential tolerance. Thus, $\delta$-agonists differ from typical antidepressants in the forced swim assay.

[Neuropsychopharmacology 26:744-755, 2002] (C) 2002 American College of Neuropsychopharmacology. Published by Elsevier Science Inc.
KEY WORDS: Delta opioid receptor; Depression; Forced swim assay; SNC80; (+)BW373U86

Current antidepressant therapy has centered around the potentiation of serotonergic and noradrenergic signaling in the central nervous system. However, other

From the Departments of Pharmacology (DCB, EMJ, JRT, JHW) and Psychology (JHW), University of Michigan Medical School, Ann Arbor, Michigan, and NIDDK (JEF, KCR), Bethesda, Maryland.

Address correspondence to: J.H. Woods, Department of Pharmacology, University of Michigan Medical School, 1301 MSRBIII, Ann Arbor, Michigan 48109-0632, Tel.: (734) 764-9133, Fax: (734) 7647118, E-mail: jhwoods@umich.edu

Received January 2, 2001; revised August 17, 2001; accepted October 16, 2001.

Online publication: $11 / 23 / 01$ at www.acnp.org/citations/ Npp112301192. classes of compounds have also been investigated and have potential antidepressant activity. One such class of agents is the opioids. Studies have been performed using a variety of different opioid system-enhancing agents that suggest an antidepressant role for opioid agonists. Such studies have demonstrated antidepressant activity with the opioid ligand cyclazocine (Fink et al. 1970; open, placebo-controlled study) and with the opioid peptide $\beta$-endorphin (Kline et al. 1977; open study). Interestingly, the enkephalinase inhibitors RB101 and BL-2401 exert an antidepressant-like action in a learned helplessness assay in rats, presumably by inhibiting the degradation of endogenous opioids (Baamonde et al. 1992; Kita et al. 1997). The effect of RB101 was reversed by the $\delta$-opioid receptor antagonist nal- 
trindole implicating the $\delta$-opioid receptor in its mechanism of action (Tejedor-Real et al. 1998). Conversely, chronic administration of the opioid antagonist naltrexone induced a depression-like syndrome indicating a general role for opioid systems in depression (Hollister et al. 1981; open, placebo-controlled study). Likewise, recent studies examining $\delta$-opioid receptor knockout mice indicated that these animals displayed a depressive syndrome again supplementing the findings of previous work with $\beta$-endorphin in demonstrating an intrinsic role for the $\delta$-opioid receptor system in the maintenance of a positive emotional state (Filliol et al. 2000).

It has also been suggested that one of the effects of electroconvulsive therapy (ECT), a widely used antidepressant treatment, is to increase the activity of endogenous opioids, such as $\beta$-endorphin (Emrich et al. 1979; Inturrisi et al. 1982). It is therefore conceivable that an opioid deficiency plays a role in depressive illness and that by countering this deficiency, either by the induction or replacement of endogenous systems, a novel and beneficial strategy to the treatment of depression may be obtained.

Recent work on nonpeptidic $\delta$-opioid receptor agonists such as BW373U86 $\left(( \pm)-\left[1\left(S^{*}\right), 2 \alpha, 5 \beta\right]-4-[[2,5-\right.$ dimethyl-4(2-propenyl)-1-piperazinyl]/(3-hydroxyphenyl)methyl]- $\mathrm{N}$, $\mathrm{N}$-diethyl-benzamide dihydrochloride) (Chang et al. $1993)$ and SNC80 ((+)-4-[( $\alpha R)-\alpha-((2 S, 5 R)-4-A l l y l-2,5-$ dimethyl-1-piperazinyl)-3-methoxybenzyl]-N,N-diethylbenzamide) (Bilsky et al. 1995) has demonstrated that these compounds produce a mild, naltrindole-reversible convulsive effect in mice (Comer et al. 1993; Hong et al. 1998; Broom et al. 2000). Convulsions that occur via the $\delta$-opioid receptor are characteristically brief (20-30 s), nonlethal and occur from approximately 4 to $15 \mathrm{~min}$ after systemic administration. A short period (5 to $10 \mathrm{~min}$ ) of catalepsy is seen following the convulsive episode after which the animals appear to make a rapid recovery. Compounds producing this $\delta$-mediated convulsive effect include BW373U86 (Comer et al. 1993), SNC80 (Hong et al. 1998) and BU48 (Broom et al. 2000). The convulsions seen with all these compounds are strikingly similar in nature thus implicating the same convulsive mechanism. It may be hypothesized that agonists acting at the $\delta$-opioid receptor, by producing the convulsion, have an ECT-like antidepressant effect (Comer et al. 1993). However, these compounds could also, as suggested by earlier experiments examining the antidepressant effects of opioids, have their own intrinsic antidepressant activity that is independent of the convulsive activity.

It is hypothesized that nonpeptidic $\delta$-opioid receptor agonists may have antidepressant-like activity. In the present study, the antidepressant potential of such compounds was evaluated using the forced swim assay. This assay involves measuring the immobility, swimming, and climbing behaviors of rats upon subsequent exposures to swimming (Porsolt et al. 1977; Detke et al. 1995). All currently approved therapeutic compounds are active in the assay by decreasing immobility scores compared to vehicle controls (Reneric and Lucki 1998). Therefore, the assay can be used with predictive validity to screen for novel compounds with potential antidepressant activity.

\section{METHODS}

\section{Chemicals}

$(+)$ BW373U86.2HCl $\left((+)-\left[1\left(S^{*}\right), 2 \alpha, 5 \beta\right]-4-[[2,5\right.$-dimethyl4-(2-propenyl)-1-piperazinyl](3-hydroxyphenyl)methyl]$\mathrm{N}, \mathrm{N}$-diethylbenzamide dihydrochloride) was synthesized according to standard protocol (Bishop and McNutt 1995), naltrindole hydrochloride (Dr. J. Lewis, University of Bath, UK), morphine sulfate (Mallinkrodt, St Louis, MO), CI977 hydrochloride (5R-( $5 \alpha, 7 \alpha, 8 \beta)-\mathrm{N}$-methyl-N[7-(1-pyrrolidinyl-1-oxaspiro[4,5]dec-8-yl]-4-benzofuranacetamide hydrochloride) (Pfizer, Ann Arbor, MI), desipramine hydrochloride (Sigma, St Louis, MO), fluoxetine hydrochloride (Lilly Research Laboratories, Indianapolis, IN), ketamine hydrochloride (Vedco Inc., St. Joseph, $\mathrm{MO}$ ) and xylazine hydrochloride (Fermenta Animal Health Co., Kansas City, MO) were all dissolved in sterile water. SNC80 base was synthesized according to standard protocol (Calderon et al. 1994) and dissolved in sterile water using a drop of $1 \mathrm{~N}$ hydrochloric acid. Doses were calculated, where appropriate, as the salt form.

\section{Animals}

Male Sprague-Dawley rats (200-350 g) were obtained from Harlan Sprague Dawley (Indianapolis, IN) and housed in groups of three to four animals unless otherwise stated. All animals were fed on a standard laboratory diet and kept on a $12 \mathrm{~h}$ light/dark cycle with lights on at 6:30 A.M. at a temperature of $21^{\circ} \mathrm{C}$. Studies were performed in accordance with the Declaration of Helsinki and with the Guide for the Care and Use of Laboratory Animals as adopted and promulgated by the National Institutes of Health. The experimental protocols were approved by the University of Michigan University Committee on the Use and Care of Animals.

\section{Forced Swim Assay}

For a measure of antidepressant-like activity, rats were subjected to the forced swim assay as previously described by Detke and colleagues (1995). Briefly, male Sprague-Dawley rats (200-350 g) were placed in a plexiglas container $(46 \mathrm{~cm}$ tall $\times 20 \mathrm{~cm}$ diameter) filled to $30 \mathrm{~cm}$ with $25^{\circ} \mathrm{C}\left( \pm 1^{\circ} \mathrm{C}\right)$ water. Two swimming sessions were conducted, a swim lasting 15 min (day 1) 
followed $24 \mathrm{~h}$ later by a test swim lasting $5 \mathrm{~min}$. An aerial view of the test swim was videotaped for later analysis and scoring. For further experiments an aerial view of the initial swim was videotaped. Cylinder water was changed after every other rat. Following each swim period, the rats were removed from the water, towel-dried and placed in a heated cage for $15 \mathrm{~min}$.

Scoring was performed by an observer blind to the treatment received by each animal. The behavior of the rats was analyzed every $5 \mathrm{~s}$ for 5 -min periods during each swim. Behavior was classified as one of three behaviors-immobility, swimming, or climbing (Detke et al. 1995). Immobility was defined as floating in the water without struggling and using only small movements to keep the head above water. Swimming was defined as moving limbs in an active manner (more than required to keep the head above water) causing movement among quadrants of the cylinder. Finally, climbing was defined as making active movements with forepaws moving in and out of the water, usually directed against the side of the cylinder. The numbers of each behavior counted during each 5-min period were totaled and averaged within each treatment group. For analysis of day 1 pool exposure, the activity scores for the total $15 \mathrm{~min}$ were also calculated. Statistical analysis was performed using 1-way ANOVA with Dunnett's post-hoc test when comparing more than one dose to control or a Student's t-test when comparing one dose to control (Graphpad Prism v.3.02, Graphpad Software, San Diego, CA). $p \leq .05$ was accepted as statistical significance.

\section{Drug Treatment}

All drugs were administered by subcutaneous injection except desipramine and fluoxetine which were injected by the intraperitoneal route. For all experiments a single dose of SNC80, morphine, CI977 or vehicle control was injected $1 \mathrm{~h}$ before the test swim. Antagonists (naltrindole) were given $15 \mathrm{~min}$ prior to agonist treatment (i.e. 75 min before test swim).

\section{Warm Water Tail Withdrawal Assay}

To ensure an active dose of opioid drug was being administered in the forced swim assay, some groups of rats were subjected to the rat warm water tail withdrawal assay (Ko et al. 2000) to measure antinociception with SNC80, morphine and C1977. The warm water tail withdrawal assay was performed one week before the forced swim assay was commenced. Briefly, rats were habituated to the tail dip using the following protocol: day 1, each rat was wrapped in a towel and was subjected to three tail dips into room temperature water; day 3, each rat was wrapped in a towel and was subjected to three tail dips into $50^{\circ} \mathrm{C}$ water spaced 30 min apart with each dip being followed by injection with sterile water. The tail withdrawal experiment was performed on day 4. Each rat was given cumulative doses of either SNC80, morphine, C1977, or vehicle control. Thirty min after each dose, the rat was examined for tail withdrawal latency by placing the terminal 1-1.5 inches of the tail into $50^{\circ} \mathrm{C}$ water. A maximum latency of $20 \mathrm{~s}$ was used at which point maximum latency was assigned. If full latency wasn't achieved the animal was immediately injected with the next dose of drug. Antinociception data was calculated as percentage antinociception using the following equation: $\%$ antinociception $=[($ Treatment latency - Vehicle latency $) /($ Maximum latency - Vehicle latency)] $\times 100$.

After the tail withdrawal assay was completed, the animals were returned to their home cages for housing prior to the start of the forced swim assay. Seven days after the tail withdrawal assay, the animals were subjected to the forced swim assay preswim $(15 \mathrm{~min})$ followed a day later by a 5-min test swim. Each animal was administered the same drug that was given during the tail withdrawal assay. Drug was administered $1 \mathrm{~h}$ before commencement of the 5-min test swim. Controls indicated that drug administered during the tail-dip procedure had no effect on subsequent activity in the forced swim assay. Only the animals used in the initial forced swim experiments (Figure 1) were previously used in the tail withdrawal procedure. Statistical analysis was performed for each drug using 1-way ANOVA with Dunnett's post-hoc test (Graphpad Prism software). $p \leq .05$ was accepted as statistical significance.

\section{Locomotor Activity and Core Body Temperature Studies}

A transmitter (model ER-4000 E-Mitter, Mini Mitter Co., Sunriver, OR) was implanted inside the peritoneum under xylazine $(10 \mathrm{mg} / \mathrm{kg})$ and ketamine $(100$ $\mathrm{mg} / \mathrm{kg}$ ) at least seven days before the initiation of locomotor and core body temperature data collection. Previous studies have demonstrated that body weights and core temperatures of rats implanted with transmitters were indistinguishable from unoperated rats of a similar age by post-operative day 5 (Houshyar 2000). The transmitter produced locomotor activity and temperature modulated signals, that were sent to a receiver (model ER-4000 Receiver, Mini Mitter Co.) placed under the cage. Data were collected and processed simultaneously by the Vital View data acquisition system (Mini Mitter Co.). Animals were singly housed for at least two days prior to the start of the experimental procedure. Animals were subjected to the forced swim assay as described above beginning with a preswim of 15 min except that a 5-min test swim was not performed on the second day. Instead, animals were injected with drug or vehicle treatment $23 \mathrm{~h}$ after the start of the pre- 


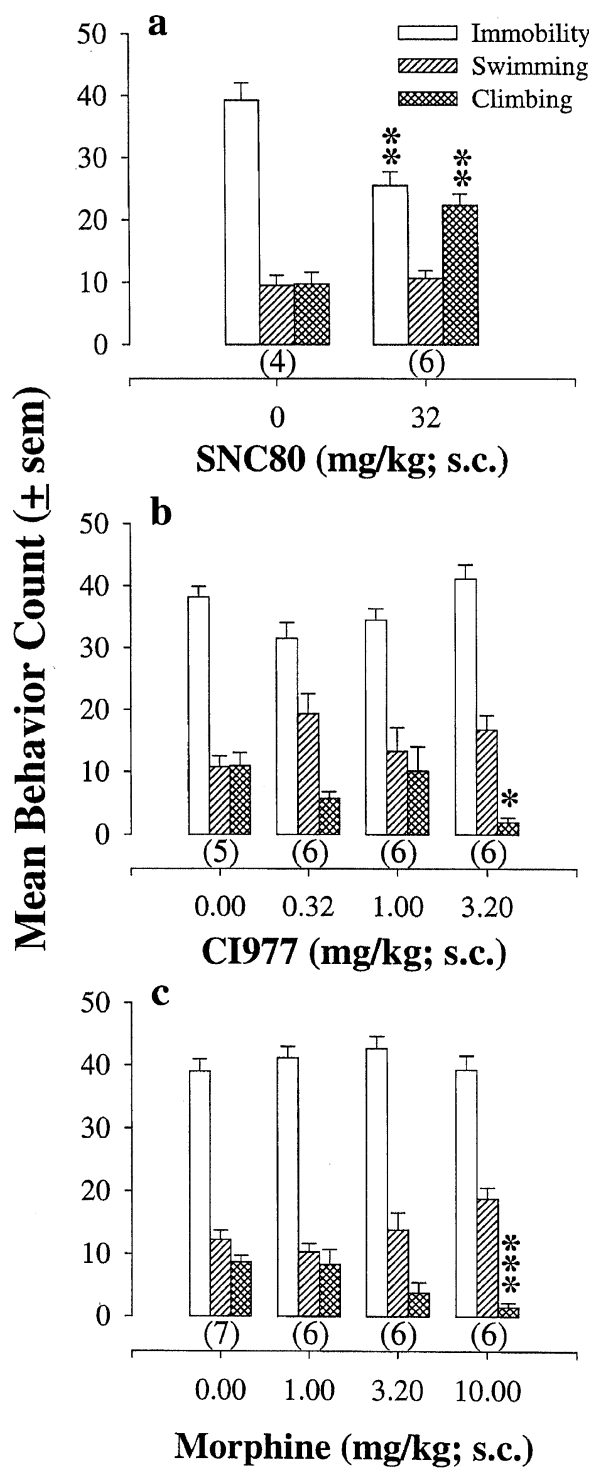

Figure 1. The effects of (a) SNC80, (b) CI977 and (c) morphine in the rat forced swim assay. Male Sprague-Dawley rats were subjected to the warm water tail dip as described in Methods. Approximately one week after the tail dip assay, all subjects were used in the forced swim assay with the same compound tested in the tail dip assay. Control experiments showed that prior exposure to compounds during the tail-dip procedure had little effect on control values in the subsequent forced swim assay. Each rat was exposed for 15 min to the swimming apparatus $24 \mathrm{~h}$ before being tested with a 5-min swim. Drug or vehicle was administered by subcutaneous injection $1 \mathrm{~h}$ before the test swim. Behavior during the swim period (immobility, swimming or climbing) was assessed every $5 \mathrm{~s}$ and total scores for each activity calculated. Numbers in parentheses corresponds to n. ${ }^{*} p<$ $.05,{ }^{* *} p<.01$ and ${ }^{* * *} p<.001$ when compared with vehicle.

swim (i.e. the same time that a drug would have been injected under the 2-day forced swim assay procedure as described above). After injection, animals were returned to their home cage. Locomotor activity data were summed and core body temperature values averaged over 5 -min intervals beginning at least $30 \mathrm{~min}$ prior to injection with drug and continuing until the termination of the experiment. Means across rats for each treatment group were calculated as time after injection $\pm 2 \mathrm{~min}$. Statistical analysis was performed using 2-way ANOVA with Tukey's post-hoc analysis for unequal N (Statsoft Statistica Software). $p<.05$ was accepted as statistical significance.

\section{RESULTS}

\section{Forced Swim Experiments}

The $\delta$-opioid selective agonist SNC80 produced antidepressant-like activity in the forced swim assay (Figure 1 , panel a). A decrease in immobility $(p<.005, \mathrm{t}=3.92$, $\mathrm{df}=8)$ was coupled to an increase in climbing ( $p<$ $.005, \mathrm{t}=4.73, \mathrm{df}=8$ ) although no significant change was seen in swimming. These changes in immobility and climbing were seen at a subcutaneous (s.c.) dose of $32 \mathrm{mg} / \mathrm{kg}$ SNC80. A к-opioid receptor agonist, CI977, produced a significant difference in immobility when using a 1-way ANOVA $\left(\mathrm{F}_{3,19}=3.84, p<.05\right)$ however, no individual differences from vehicle were identified at any dose when using Dunnett's post-hoc test (Figure 1, panel b). CI977 did not significantly alter swimming $\left(\mathrm{F}_{3,19}=1.52, p=.24\right)$ but did decrease climbing $\left(\mathrm{F}_{3,19}=\right.$ $3.22, p<.05)$. Morphine, a $\mu$-opioid receptor agonist, did not alter immobility counts $\left(\mathrm{F}_{3,21}=0.73, p=.55\right)$ but did produce a significant increase in swimming counts $\left(\mathrm{F}_{3,21}=3.62, p<.05\right)$ and a significant decrease in climbing counts $\left(\mathrm{F}_{3,21}=5.15, p<.01\right)$ (Figure 1 , panel $\mathrm{c}$ ). However, no individual swimming differences from vehicle were identified at any dose when using Dunnett's post-hoc analysis. Antinociceptive effects were seen upon injection of morphine $\left(\mathrm{F}_{3,30}=59.35, p<\right.$ $.0001)$ and $\mathrm{CI} 977\left(\mathrm{~F}_{3,26}=9.07, p<.001\right)$ in the rat warm water tail withdrawal assay at doses used in the rat forced swim assay (Figure 2). Thus, the doses of morphine and CI977 used in the rat forced swim assay were pharmacologically active. SNC80, although producing a significant decrease in tail-withdrawal latency in the tail withdrawal assay $\left(\mathrm{F}_{4,34}=3.55, p<.05\right)$ was inactive as an antinociceptive agent at all doses in this assay (Figure 2). The profile of activity of these prototypic $\mu$ and $\kappa$-opioid compounds therefore differed from SNC80 in the forced swim assay (Figure 1, panel a).

Dose-effect relationships were constructed for both SNC80 and another $\delta$-opioid receptor selective compound, $(+)$ BW373U86 (Figure 3, panels a and b respectively). Both compounds dose-dependently decreased immobility and dose-dependently increased climbing. ANOVA values for each treatment: immobility (SNC80, $\mathrm{F}_{3,27}=13.03, p<.0001 ;(+) B W 373 \mathrm{U} 86, \mathrm{~F}_{3,24}=27.08$, $p<.0001$ ), climbing (SNC80, $\mathrm{F}_{3,27}=6.02, p<.005$; 


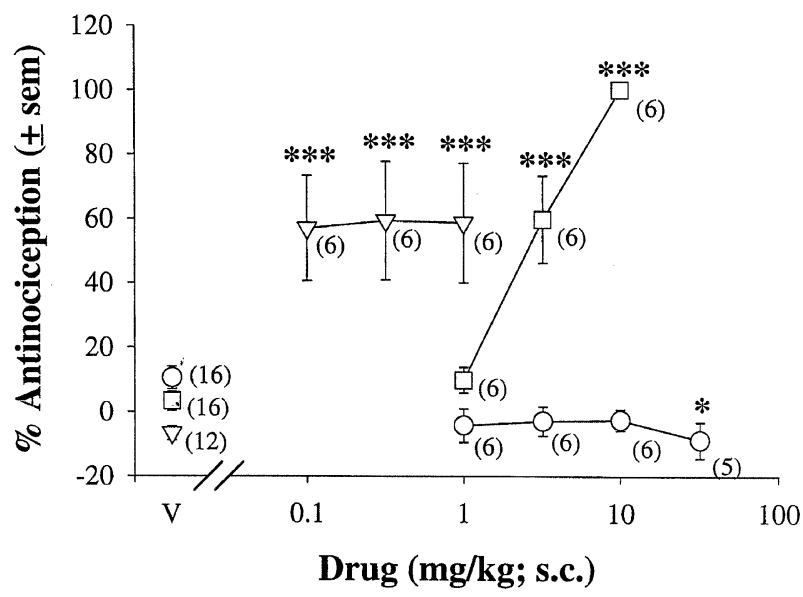

Figure 2. The antinociceptive properties of morphine ( $\square$ ), CI977 $(\nabla)$ and SNC80 $(\bigcirc)$ in the rat warm water tail dip. Rats were habituated to the tail-dip procedure as described in Methods. Each rat was then given cumulative doses of drug $30 \mathrm{~min}$ before being tested for antinociception by dipping the tail into $50^{\circ} \mathrm{C}$ water. The subsequent dose was administered immediately following the tail dip. Maximum latency to tail withdrawal was $20 \mathrm{~s}$. Numbers in parentheses corresponds to $\mathrm{n} .{ }^{*} p<.05$ and ${ }^{* * *} p<.001$ when compared with vehicle.

$(+)$ BW373U86, $\left.\mathrm{F}_{3,24}=7.42, p<.005\right)$. However, $(+)$ BW373U86 also caused an increase in swimming counts $\left(\mathrm{F}_{3,24}=9.90, p<.0005\right)$ (Figure 3, panel $b$ ). (+)BW373U86 was approximately 10-fold more potent than SNC80 and afforded a significant decrease in immobility and increase in climbing and swimming at a dose of $3.2 \mathrm{mg} / \mathrm{kg}$. The potency relationship of the two agonists is consistent with their in vitro potencies in cloned $\delta$-opioid receptor binding assays (Negus et al. 1998).

The $\delta$-opioid receptor antagonist naltrindole had no effect alone (Figure 4, panel a), but did prevent the decrease in immobility seen with SNC80 $\left(\mathrm{F}_{4,25}=35.21, p<\right.$ $.0001)$ and $(+)$ BW373U86 $\left(\mathrm{F}_{2,17}=7.79, p<.01\right)$ in the forced swim assay (Figure 4 , panels $b$ and $c$ respectively). Naltrindole also prevented the increase in climbing activity seen with administration of $\mathrm{SNC} 80\left(\mathrm{~F}_{4,25}=\right.$ $19.79, p<.0001)$ and also appeared to alter swimming $\left(\mathrm{F}_{4,25}=8.29, p<.001\right)$ however, this effect is only apparent at one intermediate dose of naltrindole and does not appear to be a trend (Figure 4, panel b).

The effect of SNC80 and (+)BW373U86 in the forced swim assay was compared to subchronic treatment with the known antidepressant compounds desipramine (Figure 5, panel a) and fluoxetine (Figure 5, panel b). Although not statistically significant both of these compounds decreased immobility (desipramine, $\mathrm{F}_{3,26}=2.72$, $p=.065$; fluoxetine, $\mathrm{F}_{3,27}=2.44, p=.086$ ). Desipramine also increased climbing albeit not statistically signifi-
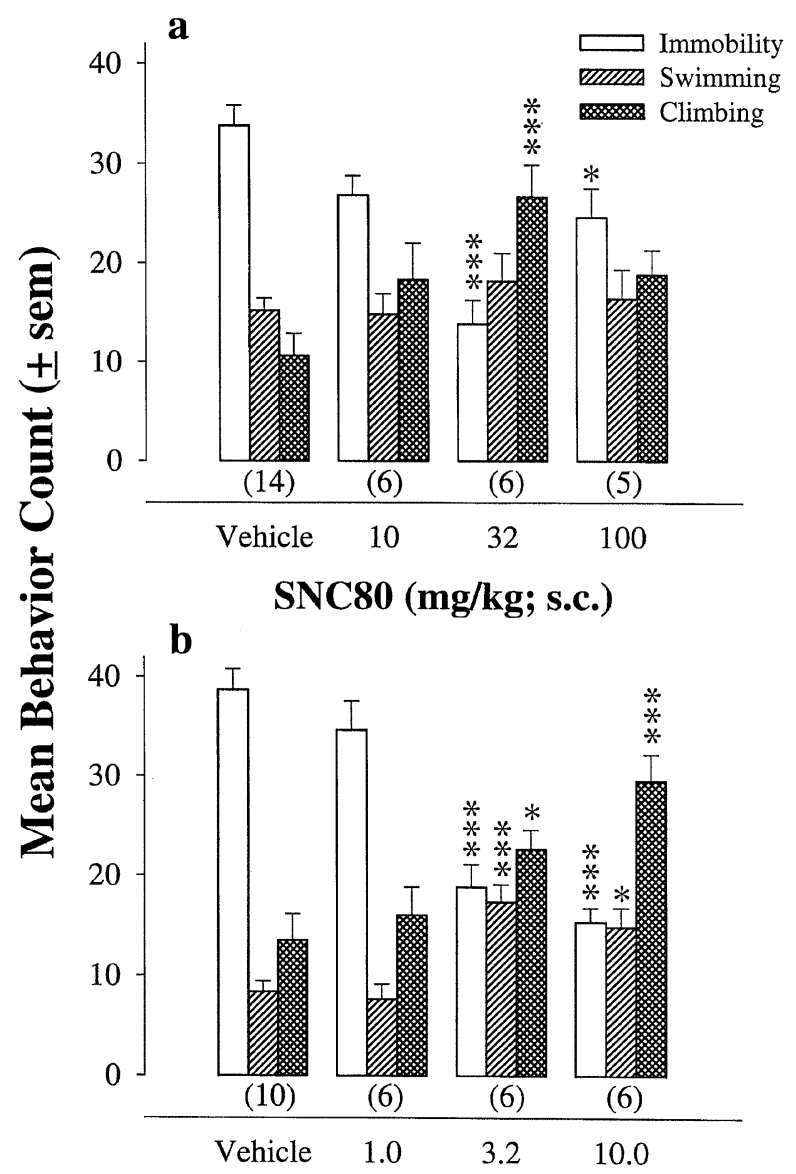

(+)BW373U86 (mg/kg; s.c.)

Figure 3. The effects of (a) SNC80 and (b) (+)BW373U86 on activity in the rat forced swim assay. Male Sprague Dawley rats were habituated for $15 \mathrm{~min}$ to the swimming apparatus $24 \mathrm{~h}$ before being tested with a 5 -min swim as described in Methods. Drug or vehicle was administered by subcutaneous injection $1 \mathrm{~h}$ before the test swim. Behavior during the swim period (immobility, swimming or climbing) was assessed every $5 \mathrm{~s}$ and total scores for each activity calculated. Numbers in parentheses correspond to $n .{ }^{*} p<.05$ and ${ }^{* * *} p<.001$ when compared with vehicle alone by Dunnett's post-hoc test.

cant $\left(\mathrm{F}_{3,26}=2.90, p=.054\right)$ while fluoxetine significantly increased swimming $\left(\mathrm{F}_{3,27}=4.52, p<.05\right)$, confirming previous findings (Detke et al. 1995).

\section{Locomotor Activity and Core Body Temperature Experiments}

In order to eliminate a false positive response in the forced swim assay due to increased locomotor activity alone, the effect of the $\mathrm{SNC} 80$ on locomotor activity was examined. A significant prolongation of increased locomotor activity was seen after handling and subcutaneous injection with SNC80 (Drug $X$ time interaction: $\left.\mathrm{F}_{62,465}=2.44, p<.0001\right)$ when compared to vehicle 


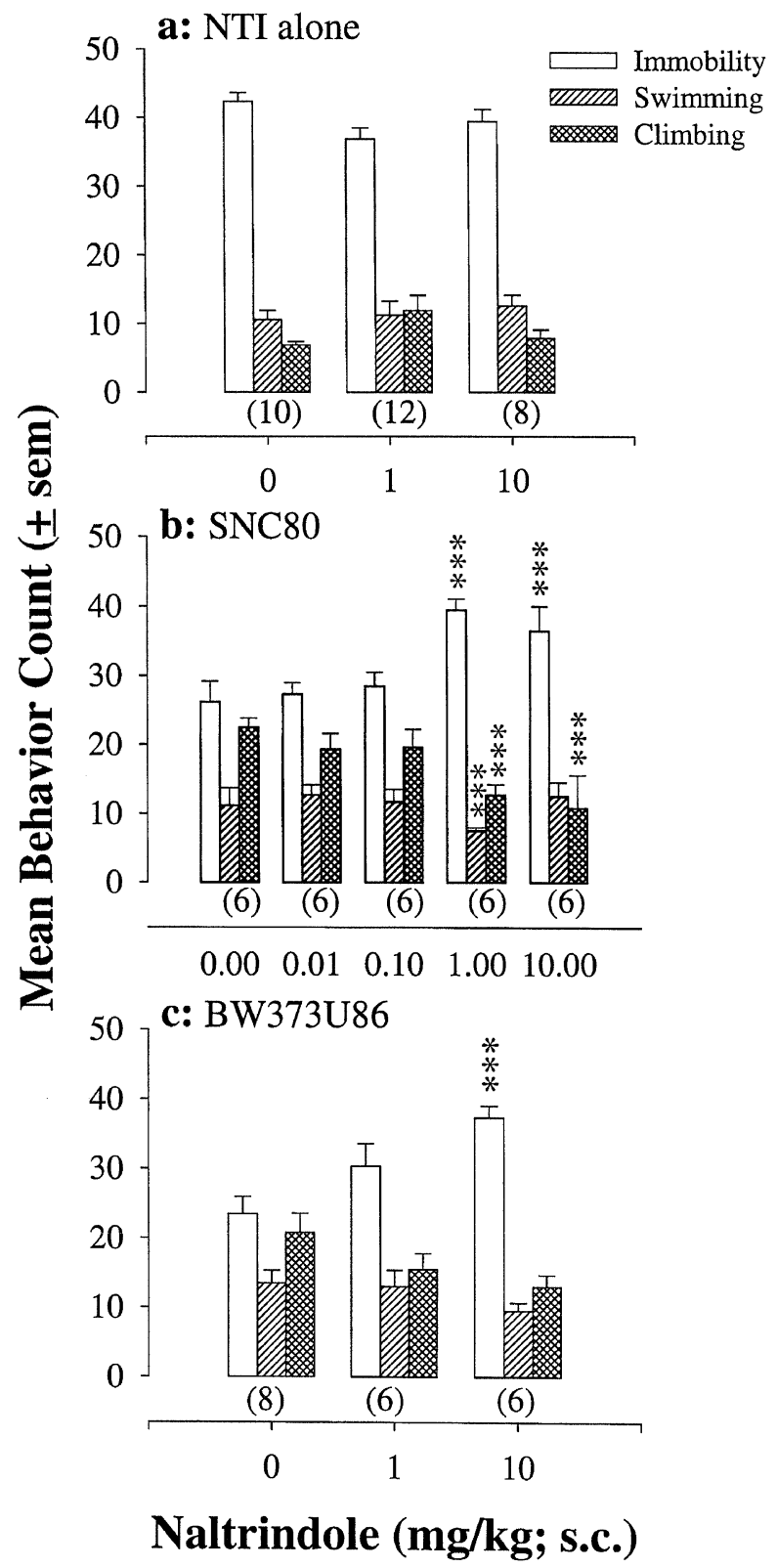

Figure 4. The effect of (a) naltrindole alone and the antagonistic effect of naltrindole on (b) SNC80 and (c) (+)BW373U86 activity in the forced swim assay. Male Sprague-Dawley rats were habituated for 15 min to the swimming apparatus $24 \mathrm{~h}$ before being tested with a 5-min swim as described in Methods. Naltrindole or vehicle was administered by subcutaneous (s.c.) injection $1 \mathrm{~h} 15 \mathrm{~min}$ before the test swim. $32 \mathrm{mg} / \mathrm{kg}$ SNC80 or $10 \mathrm{mg} / \mathrm{kg}(+) B W 373 \mathrm{U} 86$ was administered s.c. $1 \mathrm{~h}$ before the test swim. Behavior during the swim period (immobility, swimming or climbing) was assessed every $5 \mathrm{~s}$ and total scores for each activity calculated. Numbers in parentheses corresponds to $n .{ }^{* * *} p<.001$ when compared with SNC80 or $(+)$ BW373U86 alone $(0 \mathrm{mg} / \mathrm{kg}$ naltrindole) by Dunnett's post-hoc test.

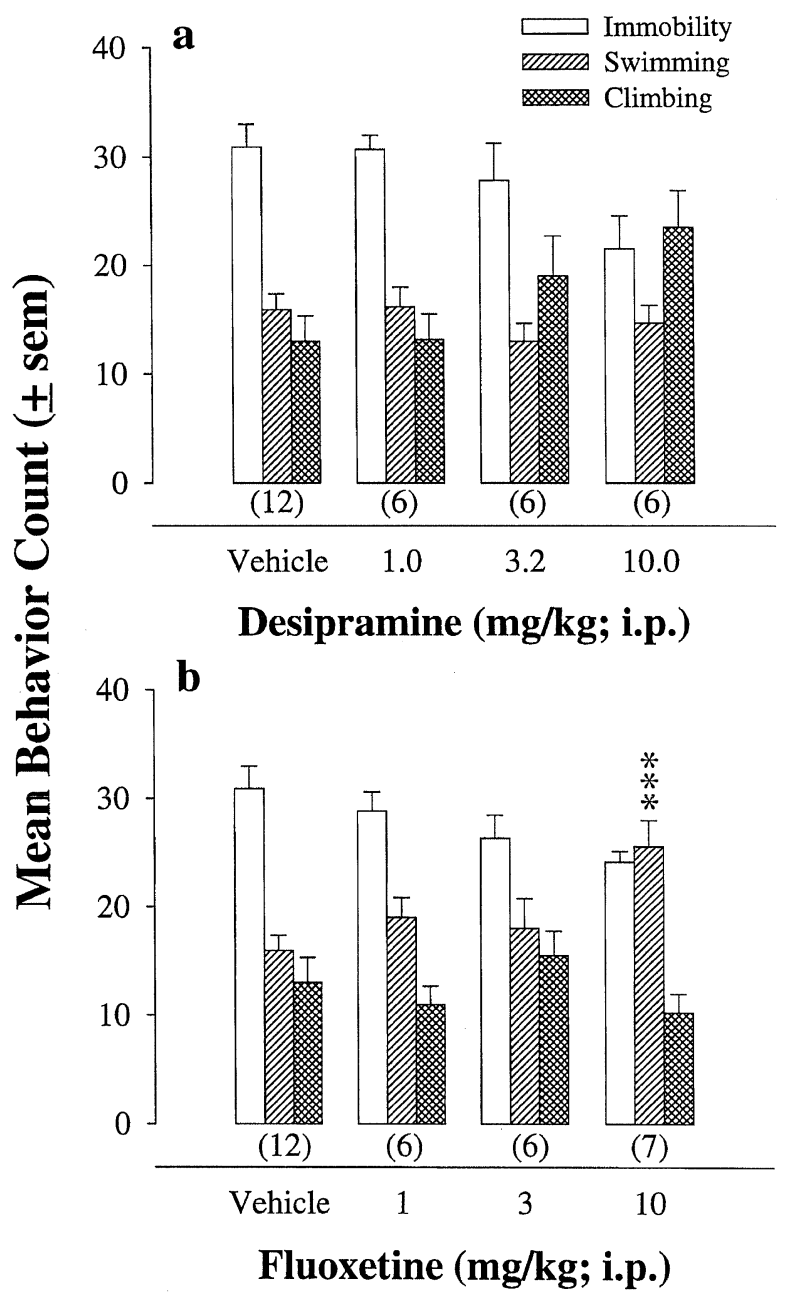

Figure 5. The effects of (a) desipramine and (b) fluoxetine on activity in the rat forced swim assay. Male Sprague Dawley rats were habituated for $15 \mathrm{~min}$ to the swimming apparatus $24 \mathrm{~h}$ before being tested with a 5-min swim as described in Methods. Drug or vehicle was administered by intraperitoneal injection at 23.5, 5 and $1 \mathrm{~h}$ before the test swim. Behavior during the swim period (immobility, swimming or climbing) was assessed every $5 \mathrm{~s}$ and total scores for each activity calculated. Numbers in parentheses correspond to $\mathrm{n}$. ${ }^{*} p<.05$ and ${ }^{* * *} p<.001$ when compared with vehicle alone by Dunnett's post-hoc test.

alone (Figure 6, panel a). Post-hoc analysis revealed an elevation of locomotor activity compared to vehicle lasting until $158 \mathrm{~min}(10 \mathrm{mg} / \mathrm{kg}$ SNC80) and $123 \mathrm{~min}$ after injection (32 mg/ $\mathrm{kg}$ SNC80).

As an increase in locomotor activity was seen at $60 \mathrm{~min}$ after injection with $32 \mathrm{mg} / \mathrm{kg}$ SNC80, the dose active in the forced swim assay, a forced swim assay was performed using a 3-h pretreatment of SNC80 (locomotor activity had returned to baseline values and did not significantly differ from baseline at $123 \mathrm{~min}$ after injection of 32 $\mathrm{mg} / \mathrm{kg}$ SNC80). A 3-h pretreatment of $32 \mathrm{mg} / \mathrm{kg}$ SNC80 produced a significant reduction in immobility $(p<.001$, 

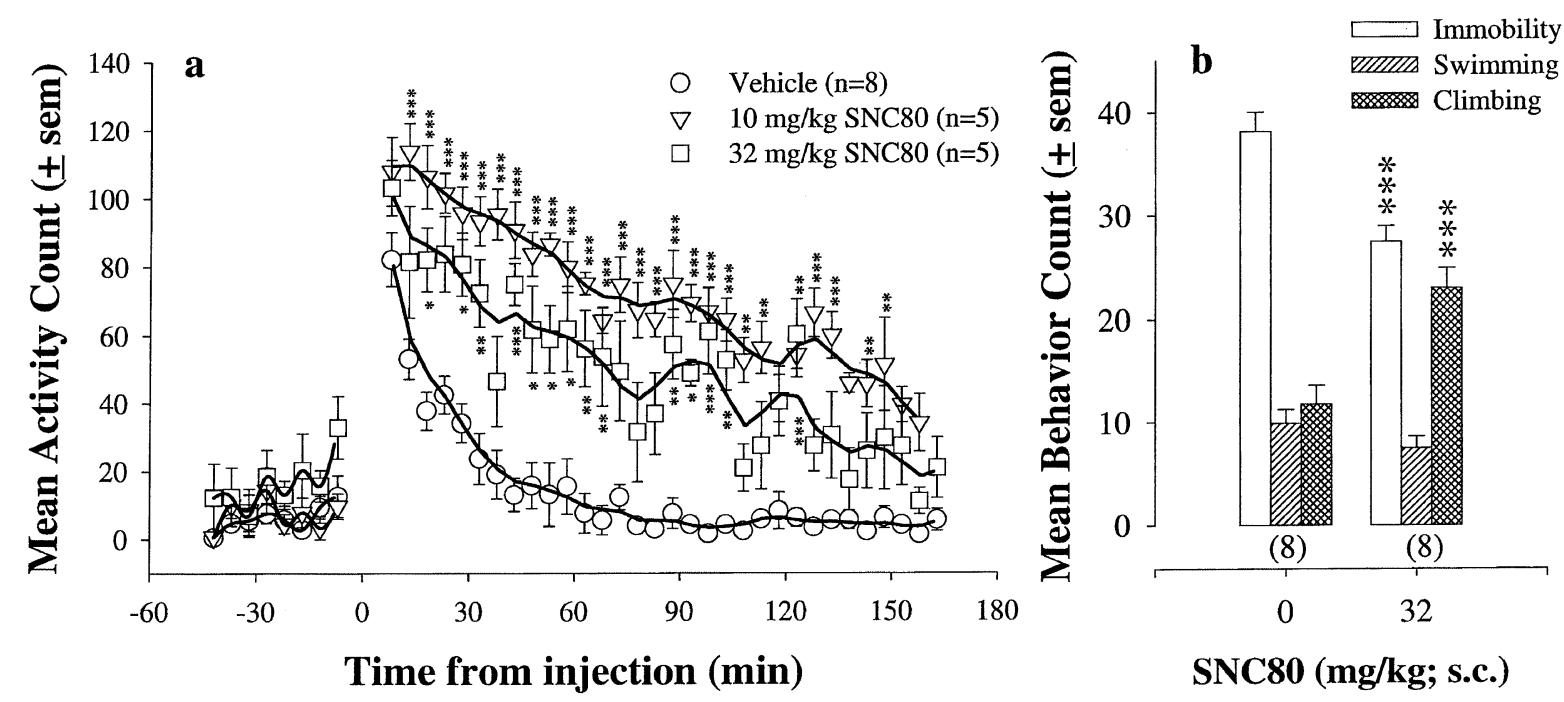

Figure 6. (a) The effect of SNC80 on locomotor activity. Rats were implanted with ER-4000 E-Mitters and subjected to the locomotor activity assay as described in Methods. Rats were subcutaneously injected with either SNC80 or vehicle at time 0 and activity data collected. Data was assessed using cubic spline curves for preinjection baseline values and LOWESS curves for post-injection values (GraphPad Prism Software). Statistical significance was assigned using 2-way ANOVA (Statsoft Statistica Software). ${ }^{*} p<.05,{ }^{* *} p<.01$ and ${ }^{* * *} p<.001$ when compared with vehicle using Tukey's post-hoc analysis for unequal N (statistical significance shown directly above (for $10 \mathrm{mg} / \mathrm{kg}$ SNC80) or beneath (for $32 \mathrm{mg} / \mathrm{kg} \mathrm{SNC80)} \mathrm{the} \mathrm{appro-}$ priate symbol). (b) The effect of a single injection of $32 \mathrm{mg} / \mathrm{kg}$ SNC 80 given $3 \mathrm{~h}$ before testing in the forced swim assay. Male Sprague Dawley rats were habituated for $15 \mathrm{~min}$ to the swimming apparatus $24 \mathrm{~h}$ before being tested with a 5-min swim as described in Methods. Drug or vehicle was administered by subcutaneous injection at $3 \mathrm{~h}$ before the test swim. Behavior during the swim period (immobility, swimming or climbing) was assessed every $5 \mathrm{~s}$ and total scores for each activity calculated. Numbers in parentheses correspond to $n .{ }^{* * *} p<.001$ when compared with vehicle alone by 2-tailed Student's $t$-test.

$\mathrm{t}=4.42, \mathrm{df}=14)$ and a significant increase in climbing $(p=.001, \mathrm{t}=4.16, \mathrm{df}=14)$ (Figure 6, panel b).

Injection with SNC80 was seen to produce small but significant changes in core body temperature (Drug $\mathrm{X}$ time interaction: $\mathrm{F}_{64,480}=10.15, p<.0001$ ) when compared to vehicle alone (Figure 7). A dose of $10 \mathrm{mg} / \mathrm{kg}$ SNC80 produced no statistically significant changes over time when compared to vehicle alone (by Tukey's post-hoc analysis for unequal N). SNC80 (32 mg/ kg) produced an initial drop in temperature followed by an increase that eventually merged with the temperature of animals that had received $10 \mathrm{mg} / \mathrm{kg}$ SNC80 and vehicle (during this latter stage, the effects of $10 \mathrm{mg} / \mathrm{kg}$ and $32 \mathrm{mg} / \mathrm{kg}$ SNC80 did not statistically differ from vehicle control using post-hoc analysis).

\section{Day 1 Versus Day 2 Swim Effects in the Forced Swim Assay}

Drug-induced decreases in immobility in the forced swim assay may be due to interference with a mechanism that occurs between day 1 and day 2 of the assay such as learning, memory, or adaptation to stress. This possibility was studied by examining whether fluoxetine, desipramine, and $\mathrm{SNC} 80$ would also reduce immobility on day 1 . A single dose of SNC80 given to animals naive to the swimming conditions $1 \mathrm{~h}$ before the day 1 swim appeared to be more active than subchronic dosing (Figure 8). When analyzed by a repeated measures ANOVA, immobility scores showed a significant interaction between drug (vehicle or SNC80), time period (first, second, or third $5 \mathrm{~min}$ ) and dosing regimen (acute or subchronic) $\left(\mathrm{F}_{2,38}=3.39, p<.05\right)$. Swimming scores showed a significant difference in drug treatment alone $\left(\mathrm{F}_{1,19}=10.86, p<.01\right)$ and a significant interaction between drug treatment and time period $\left(\mathrm{F}_{2,38}=3.83, p<\right.$ .05). However, no interaction was seen for drug, time period and dosing regimen $\left(\mathrm{F}_{2,38}=3.83, p=.66\right)$. Although close to significance, climbing scores showed no interaction between drug, time period and dosing regimen $\left(\mathrm{F}_{2,38}=3.23, p=.051\right)$. However, drug treatment $\left(\mathrm{F}_{1,19}=8.16, p=.01\right)$ and time period $\left(\mathrm{F}_{2,38}=88.68, p<\right.$ $.0001)$ factors were significantly different alone. A significant interaction was also seen for climbing counts between drug treatment and dosing regimen $\left(\mathrm{F}_{1,19}=\right.$ $5.19, p<.05)$.

After acute dosing desipramine and fluoxetine produced some changes in behavior during the day 1 swim when assessed in animals naive to the swimming conditions (Figure 9, panels a-d). When analyzed by a repeated measures ANOVA, immobility scores showed a significant effect over time $\left(\mathrm{F}_{2,60}=\right.$ 


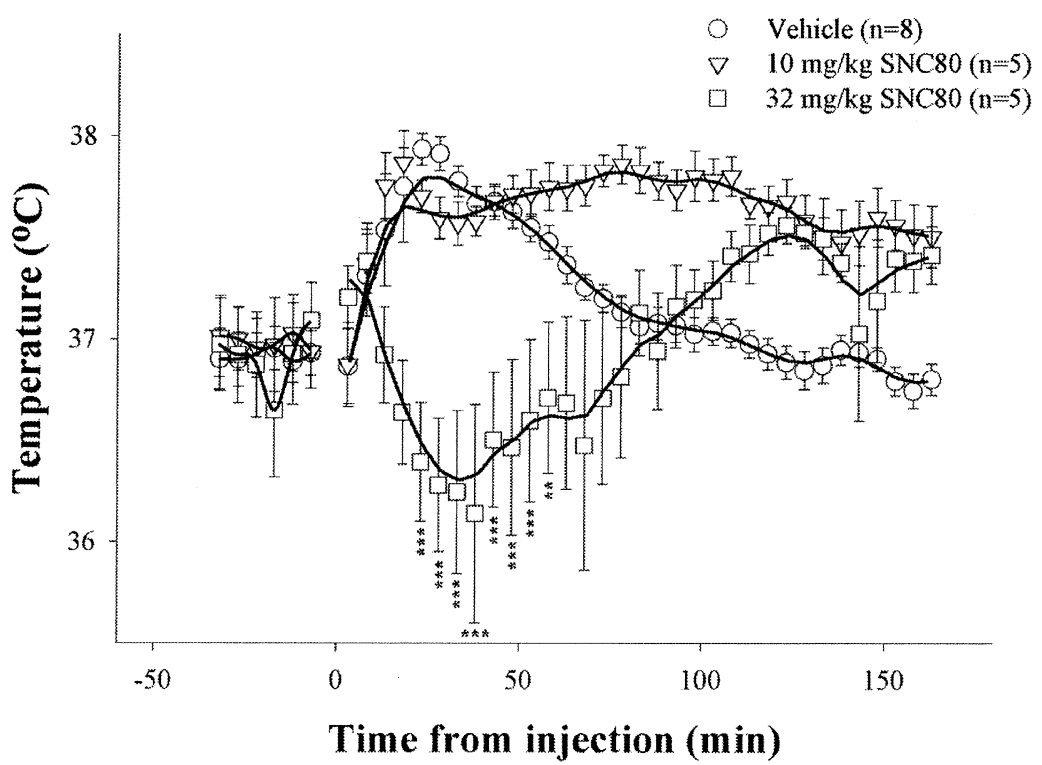

Figure 7. The effect of SNC80 on core body temperature. Rats were implanted with ER-4000 E-Mitters and subjected to temperature assessment as described under Methods. At time 0, rats were injected subcutaneously with either SNC80 or vehicle and temperature data collected over the subsequent test period. Data were assessed using cubic spline curves for preinjection baseline values and LOWESS curves for post-injection values (GraphPad Prism Software). Statistical significance was assigned using 2-way ANOVA. ${ }^{*} p<.05,{ }^{* *} p<.01$ and ${ }^{* * *} p<.001$ when comparing $32 \mathrm{mg} / \mathrm{kg}$ SNC80 to vehicle using Tukey's post-hoc analysis for unequal N (statistical significance shown directly beneath the appropriate symbol).

67.27, $p<.0001)$ and a significant interaction between drug treatment and time $\left(\mathrm{F}_{4,60}=2.58, p<.05\right)$. By referring to Figure 9, it is clear that drug effects occur in the first 5-min period. Swimming showed only a sig- nificant effect over time $\left(\mathrm{F}_{2,60}=5.09, p<.01\right)$. Finally, climbing scores displayed significant drug treatment $\left(\mathrm{F}_{2,30}=6.95, p<.01\right)$ as well as time $\left(\mathrm{F}_{2,60}=85.97, p<\right.$ $.0001)$ effects. No significant interactions between drug

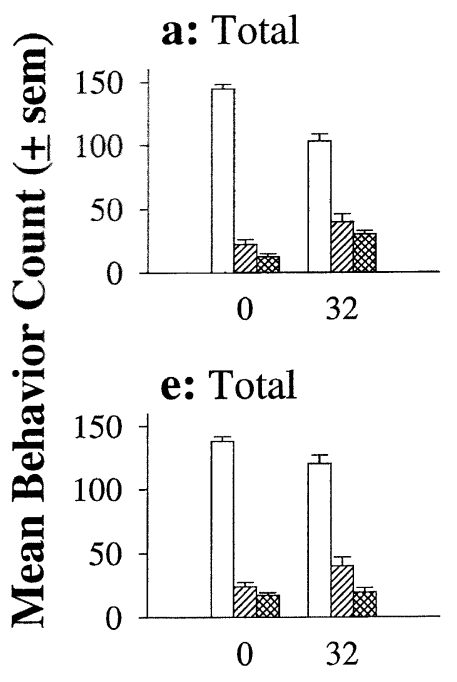

b: 1 st 5 min

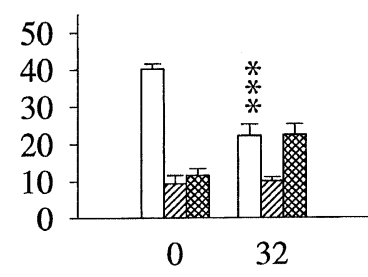

f: 1 st $5 \mathrm{~min}$

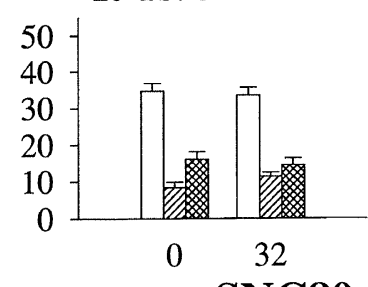

c: $2 \mathrm{nd} 5 \mathrm{~min}$

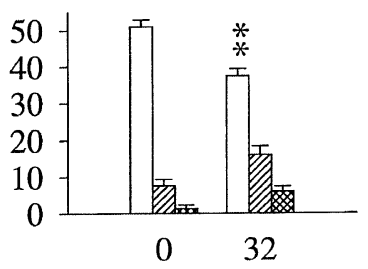

g: 2nd $5 \mathrm{~min}$

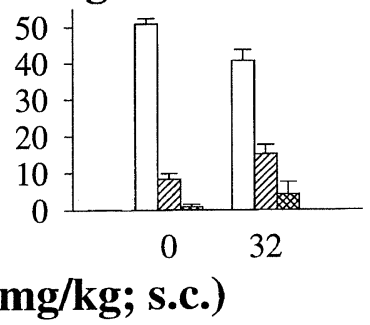

d: $3 \mathrm{rd} 5 \mathrm{~min}$

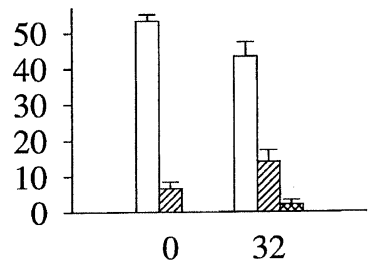

h: 3 rd $5 \mathrm{~min}$

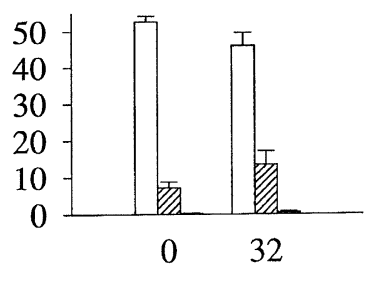

Figure 8. Effect of SNC80 on activity in the rat forced swim assay. (a-d) Drug or vehicle was administered by subcutaneous injection $1 \mathrm{~h}$ before a 15-min swim. (e-h) Drug or vehicle was administered by subcutaneous injection at 23.5, 5 and $1 \mathrm{~h}$ before a 15-min swim. Animals were not pre-exposed to the swimming apparatus. Behavior during the swim period (immobility, swimming or climbing) was assessed every $5 \mathrm{~s}$ and total scores for each activity calculated. Scores were totaled for (a and e) the complete swim period, ( $\mathrm{b}$ and $\mathrm{f}$ ) the first $5 \mathrm{~min}$, (c and $\mathrm{g}$ ) the second $5 \mathrm{~min}$ and ( $\mathrm{d}$ and $\mathrm{h}$ ) the final $5 \mathrm{~min}$ of the swim. Solid bar represents immobility, diagonal single-hatched bar represents swimming and diagonal double-hatched bar represents climbing activity. $\mathrm{n}=5-6 .{ }^{* *} p<.01$ and ${ }^{* * *} p<.001$ when compared to vehicle alone by Tukey-Kramer post-hoc analysis after repeated measures ANOVA (SAS Software v. 8.2, SAS Institute Inc., Cary, NC). 

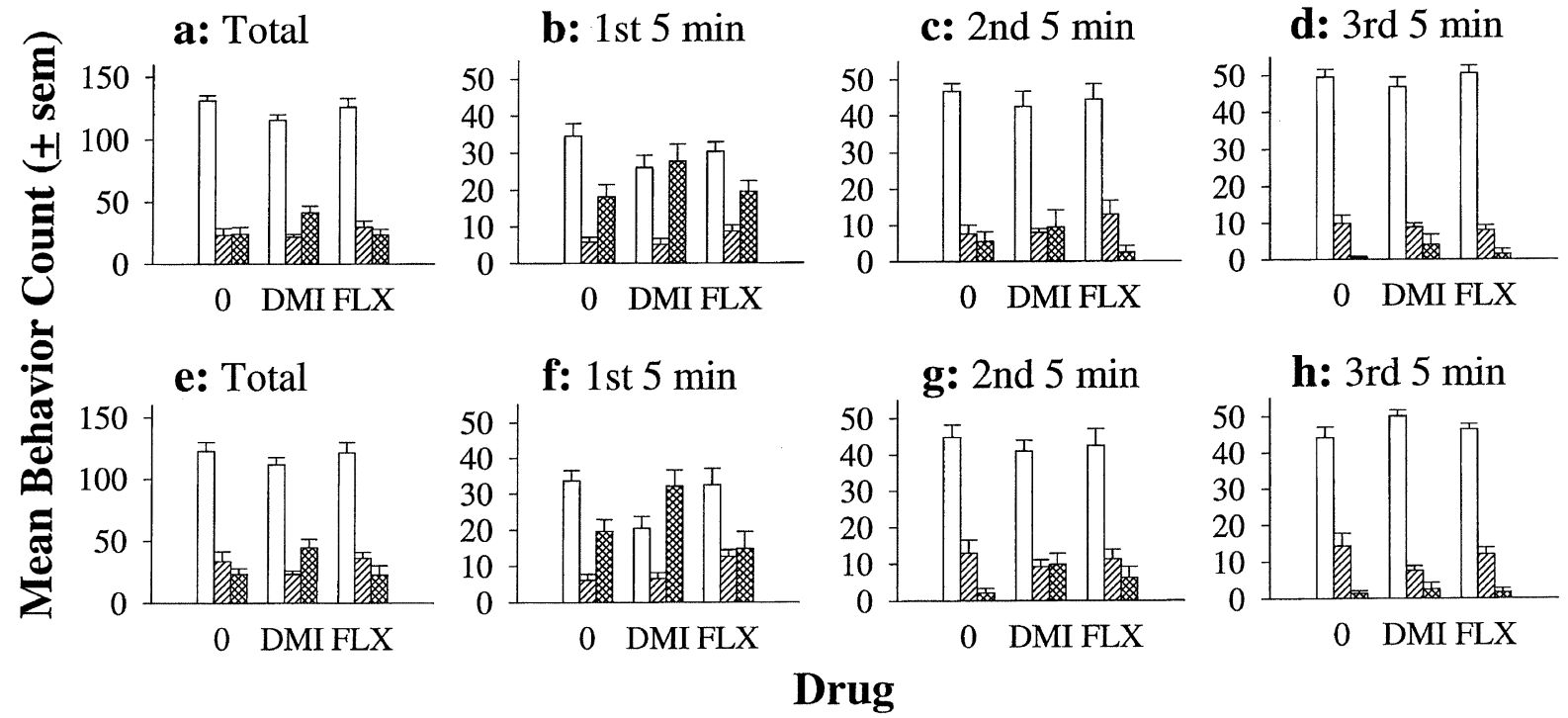

Figure 9. Effect of desipramine (DMI) and fluoxetine (FLX) on activity in the rat forced swim assay. (a-d) Drug (10 mg/kg) or vehicle was administered by intraperitoneal injection $1 \mathrm{~h}$ before a $15-\mathrm{min}$ test swim. (e-h) Drug (10 mg/kg) or vehicle was administered by intraperitoneal injection at 23.5, 5 and $1 \mathrm{~h}$ before a 15-min test swim. Animals were not pre-exposed to the swimming apparatus. Behavior during the swim period (immobility, swimming or climbing) was assessed every $5 \mathrm{~s}$ and total scores for each activity calculated. Scores were totaled for (a and e) the complete swim period, (b and f) the first 5 min, (c and $\mathrm{g}$ ) the second $5 \mathrm{~min}$ and ( $\mathrm{d}$ and $\mathrm{h}$ ) the final $5 \mathrm{~min}$ of the swim. Solid bar represents immobility, diagonal singlehatched bar represents swimming and diagonal double-hatched bar represents climbing activity. $\mathrm{n}=6$.

treatment, time period and dosing regimen were seen for any of the behavior counts (Immobility: $\mathrm{F}_{4,60}=1.04$, $p=.39$; Swimming: $\mathrm{F}_{4,60}=1.67, p=.17$; Climbing: $\mathrm{F}_{4,60}=$ $1.1, p=.37)$.

\section{DISCUSSION}

The nonpeptidic $\delta$-opioid receptor agonists SNC80 and $(+)$ BW373U86 were both active in the rat forced swim assay by decreasing immobility. This profile of activity is similar to known antidepressants that have been previously tested and used to validate the forced swim assay as an indicator of potential antidepressant activity (e.g. Borsini and Meli 1988). SNC80 is a highly selective $\delta$-opioid receptor agonist with a 495 -fold selectivity for the $\delta$-opioid receptor over the $\mu$-opioid receptor and a 248-fold selectivity over the $\kappa$-opioid receptor (Bilsky et al. 1995). Previous studies of SNC80 have demonstrated $\delta$-mediated convulsant activity and $\delta$-mediated antinociceptive activity in the mouse acetic acid-induced abdominal stretch assay (Hong et al. 1998). The activity of SNC80 in the rat forced swim assay was also mediated via the $\delta$-opioid receptor since the $\delta$-opioid selective antagonist naltrindole prevented SNC80 effects in this assay, even at low doses. Also, although the $\mu$-opioid receptor agonist morphine and the $\kappa$-selective agonist C1977 did show some effects in this assay, both failed to show a profile of activity consistent with po- tential antidepressant activity in this test even at doses active in the rat warm water tail withdrawal assay (C1977, although producing a significant, yet unidentified doserelated change in immobility, also produced a significant decrease in climbing activity). These results suggest that, of the opioid compounds tested, only $\delta$-opioid receptor agonists have a clear antidepressant profile of action in the forced swim assay. This correlates to recent findings that $\delta$-opioid receptor knockout mice appear to have an altered emotional state that is consistent with a depressed mood (Filliol et al. 2000).

Previous experiments have indicated that an increase in one of the two activities in the forced swim assay is indicative of the mechanism by which the antidepressant may act. For example, agents that inhibit serotonin reuptake such as fluoxetine increase swimming behavior while agents that act by preventing norepinephrine or dopamine reuptake (e.g. desipramine and buproprion, respectively) increase climbing activity (Detke et al. 1995; Reneric and Lucki 1998). However, all antidepressants primarily cause a decrease in immobility. These results have been confirmed in this study; although not statistically significant, desipramine produced an increase in climbing with a decrease in immobility and fluoxetine produced an increase in swimming (statistically significant) with a decrease in immobility. Therefore, SNC80 has a profile of action more like that of norepinephrine or dopaminergic reuptake inhibitors. Interestingly, (+)BW373U86 increases both swimming and climbing and therefore appears to have 
an effect involving a combination of antidepressant actions such as that shown by high doses of the mixed reuptake inhibitor venlafaxine or by combinations of differently-acting antidepressants (Reneric and Lucki 1998). This differs from the effects of SNC80 and may suggest a slightly different mechanism of action, although SNC80 also appears to increase swimming under certain circumstances (i.e., second 5-min period of day 1 swim; Figure 8, panels $\mathrm{c}$ and g). Thus $\delta$-agonists cannot be categorized with either class of current antidepressant compounds by their actions in the rat forced swim assay.

Upon initial pool exposure, acute and subchronic dosing of SNC80 displays a markedly different profile of action when compared to both desipramine and fluoxetine. The two known antidepressants only produced small effects when given by a subchronic dosing schedule or by acute dosing. However, with SNC80 acute dosing provided a greater drug effect than subchronic dosing. These observations indicate that, as well as not easily being classified in the categories of current antidepressants, SNC80 may have a different mechanism of action than both the major classes of such compounds. These studies were performed without a habituation swim to eliminate any effect that the drugs may have on learning or memory processes that may occur between day 1 and day 2 swims. Indeed, such factors involved in the day 1 swim do not appear to play a role in the activity of these drugs on the day 2 swim. For example, all three drugs displayed antidepressant-like activity to some degree, whether animals were pre-exposed to the swim apparatus or not. Thus, factors thought to be induced upon preexposure to swimming such as memory, learning and adaptation to stress do not play a role in the activity of either known antidepressant agents or that of $\delta$-opioid receptor agonists.

The decrease in effectiveness of SNC80 from a single dose to subchronic dosing may indicate tolerance development. Previous studies characterizing the convulsant effects of BW373U86 and SNC80 have indicated that both compounds have a very rapid tolerance development that is evident $24 \mathrm{~h}$ after a single administration of either drug (Comer et al. 1993; Hong et al. 1998).

A valid concern over the activity of drugs in the rat forced swim assay is whether increased locomotion could produce decreased immobility in the forced swim assay. SNC80 and ( \pm )BW373U86 have previously been shown to produce locomotor stimulation via a $\delta$-opioid receptor-mediated mechanism (Spina et al. 1998). Although it is possible that locomotor activity has a partial role in the activity of $\delta$-opioid receptor agonists, it is unlikely that it is the sole major factor producing the decrease in immobility. Indeed, a dual separation of locomotor effects and antidepressant-like effects was seen in this study. Firstly, although locomotor activity was elevated upon injection of SNC80, the elevation with 10 $\mathrm{mg} / \mathrm{kg}$ was as high, if not higher, than that produced by $32 \mathrm{mg} / \mathrm{kg}$. As $10 \mathrm{mg} / \mathrm{kg}$ did not produce significant antidepressant-like effects in the forced swim assay, it is unlikely that the antidepressant-like activity of 32 $\mathrm{mg} / \mathrm{kg}$ SNC80 is due solely to its locomotor stimulation. These results are consistent with studies by Spina and colleagues (1998) who found significant increases in locomotor activity at doses of 2.5 to $10 \mathrm{mg} / \mathrm{kg}$ SNC80. Thus a discrepancy exists between the doses of SNC80 required to produce locomotor activity and those required to produce changes in activity in the forced swim assay. Secondly, the antidepressant-like activity of $32 \mathrm{mg} / \mathrm{kg}$ SNC80 persisted at $3 \mathrm{~h}$ post-injection. By this time point, the stimulation of locomotor activity had returned to baseline values indicating that this effect was not playing any role in the antidepressant activity seen after this period. Although it may be possible that a certain residual locomotor effect may remain in the animals $3 \mathrm{~h}$ after administration of 32 $\mathrm{mg} / \mathrm{kg}$ SNC80 and that this effect may only be expressed under periods of stress (such as swimming), the dual separation of the locomotor and antidepressant-like effects suggests otherwise. However, further studies are currently being performed to further assess the role of $\delta$-opioid-mediated locomotor increases on changes in forced swim assay behavior. Interestingly some antidepressant compounds such as buproprion, nomifensine, and amineptine stimulate an increase in locomotor activity indicating that presence of locomotor changes does not negate the presence of antidepressant properties (Samanin et al. 1977; Cooper et al. 1980; Maj 1980).

Previous studies have characterized the convulsant properties of nonpeptidic $\delta$-opioid receptor agonists (Comer et al. 1993; Hong et al. 1998; Broom et al. 2000). The convulsions seen with these compounds may contribute to activity in the forced swim assay. Although rats were not studied for convulsive activity in the present study, some animals were observed convulsing. Other studies (Broom and Jutkiewicz, unpublished data) have demonstrated that convulsions occur in some animals at $32 \mathrm{mg} / \mathrm{kg}$ SNC80 (s.c.) and in nearly all animals at 100 $\mathrm{mg} / \mathrm{kg}$ SNC80 (s.c.). It is unlikely that a convulsion is exclusively required for the activity of $\delta$-opioid receptor agonists in the forced swim assay or it would be expected that a greater effect would be seen at $100 \mathrm{mg} / \mathrm{kg}$ than at $32 \mathrm{mg} / \mathrm{kg}$. In fact, the activity of SNC80 in the swim assay appears to be U-shaped with $32 \mathrm{mg} / \mathrm{kg}$ giving a greater reduction in immobility than $100 \mathrm{mg} / \mathrm{kg}$. It must be pointed out that, due to the rapid and short nature of the $\delta$-mediated convulsions, it is highly unlikely that convulsions were occurring during the swim period. In animals seen to convulse during the course of this study, convulsions have been similar to those reported in mice (Comer et al. 1993; Hong et al. 1998; Broom et al. 2000). Brief myoclonic twitches preceded a 
brief period of nonlethal clonic movements of forepaws and face (30-45 s). This was usually followed by a short period of catalepsy. In all cases, the convulsion and subsequent catalepsy ended by $20 \mathrm{~min}$ post-injection. Therefore, behavior in the forced swim assay is probably not confounded by convulsive activity while the animal is in the water.

Furthermore, core body temperature changes do not appear to play a role in the antidepressant-like effect of $\delta$-opioid receptor agonists. Core body temperature changed upon injection of 10 or $32 \mathrm{mg} / \mathrm{kg}$ SNC80; 10 $\mathrm{mg} / \mathrm{kg}$ SNC80 causing a prolonged, though not statistically significant, increase in temperature while $32 \mathrm{mg} / \mathrm{kg}$ SNC80 caused an initial hypothermic effect followed by a steady increase to values above, but not statistically significant from vehicle alone. Although $10 \mathrm{mg} / \mathrm{kg}$ and $32 \mathrm{mg} / \mathrm{kg}$ SNC80 produced differing responses in core body temperature and only $32 \mathrm{mg} / \mathrm{kg}$ SNC 80 produced an antidepressant-like effect, the antidepressant-like effect occured at both $1 \mathrm{~h}$ after injection during the hypothermia and at $3 \mathrm{~h}$, when temperature had returned to vehicle levels or above. Therefore, the antidepressantlike activity produced by $32 \mathrm{mg} / \mathrm{kg}$ SNC 80 cannot be readily associated with changes in core body temperature.

In conclusion, the nonpeptidic $\delta$-opioid receptor agonists SNC80 and (+)BW373U86 both produced a decrease in immobility with associated increases in either climbing or swimming in the rat forced swim assay. The effect was present with both acute and subchronic dosing regimens, although a more pronounced effect was seen with acute dosing that contrasts with the activity of the known antidepressants desipramine and fluoxetine. The effect of SNC80 was mediated via the $\delta$-opioid receptor and did not appear to rely on a preexposure to the swimming apparatus thus eliminating the possibility that the activity of the drug in this assay was due to effects on learning, memory, or stress adaptation. This study suggests that $\delta$-opioid receptor agonists are therefore strong candidates for possessing potential antidepressant activity and should be further studied in this regard. Although initial results indicate that locomotor activity is not playing a role in the antidepressant-like properties of these compounds, studies should also be undertaken to fully determine the roles of locomotor activity increases in these effects. Furthermore, the presence of $\delta$-mediated convulsive activity in rats prior to swimming will be investigated.

\section{ACKNOWLEDGMENTS}

The authors would like to thank Kathy Welch from the University of Michigan Center for Statistical Consultation and Research for help with statistical analyses. Research supported by USPHS grants DA00254, GM07767 and DA07267.

\section{REFERENCES}

Baamonde A, Dauge V, Ruiz-Gayo M, Fulga IG, Turcaud S, Fournie-Zalushi M-C, Roques BP (1992): Antidepressanttype effects of endogenous enkephalins protected by systemic RB101 are mediated by opioid $\delta$ and dopamine $D_{1}$ receptor stimulation. Eur J Pharmacol 216:157-166

Bilsky EJ, Calderon SN, Wang T, Bernstein RN, Davis P, Hruby VJ, McNutt RW, Rothman RB, Rice KC, Porreca F (1995): SNC80, a selective nonpeptidic and systemically active opioid delta agonist. J Pharmacol Exp Ther 273:359-366

Bishop MJ, McNutt RW (1995): An efficient synthesis of the benzhydrylpiperazine delta opioid agonist (+)-BW373U86. Bioorg Med Chem Lett 5:1311-1314

Borsini F, Meli A (1988): Is the forced swimming test a suitable model for revealing antidepressant activity? Psychopharmacol 94:147-160

Broom DC, Guo L, Coop A, Husbands SM, Lewis JW, Woods JH, Traynor JR (2000): BU48: A novel buprenorphine analog that exhibits $\delta$-opioid-mediated convulsions but not $\delta$-opioid-mediated antinociception in mice. J Pharmacol Exp Ther 294:1195-1200

Calderon SN, Rothman RB, Porreca F, Flippen-Anderson JL, McNutt RW, Xu H, Smith LE, Bilsky EJ, Davis P, Rice KC (1994): Probes for narcotic receptor mediated phenomena. 19. Synthesis of $(+)-4-[(\alpha R)-\alpha-((2 S, 5 R)-4$-allyl-2,5 dimethyl-1-piperazinyl)-3-methoxybenzyl]-N,N-diethylbenzamide (SNC80): A highly selective, nonpeptide $\delta$ opioid receptor agonist. J Med Chem 37:2125-2128

Chang K-J, Rigdon GC, Howard JL, McNutt RW (1993): A novel, potent and selective nonpeptidic delta opioid receptor agonist BW373U86. J Pharmacol Exp Ther 267:852-857

Comer SD, Hoenicke EM, Sable AI, McNutt RW, Chang K-J, DeCosta BR, Mosberg HI, Woods JH (1993): Convulsive effects of systemic administration of the delta opioid agonist BW373U86 in mice. J Pharmacol Exp Ther 267:888-895

Cooper BR, Hester TJ, Maxwell RA (1980): Behavioral and biochemical effects of the antidepressant bupropion (Wellbutrin): Evidence for selective blockade of dopamine uptake in vivo. J Pharmacol Exp Ther 215:127-134

Detke MJ, Rickels M, Lucki I (1995): Active behaviors in the rat forced swimming test differentially produced by serotonergic and noradrenergic antidepressants. Psychopharmacol 121:66-72

Emrich HM, Hollt V, Kissling W, Fischler M, Laspe H, Heinemann H, von Zerssen D, Herz A (1979): beta-Endorphin-like immunoreactivity in cerebrospinal fluid and plasma of patients with schizophrenia and other neuropsychiatric disorders. Pharmakopsychiatr Neuropsychopharmakol 12:269-276

Filliol D, Ghozland S, Chluba J, Martin M, Matthes HWD, Simonin F, Befort K, Gaveriaux-Ruff C, Dierich A, LeMeur M, Valverde O, Maldonado R, Kieffer BL (2000): Mice deficient for $\delta$ - and $\mu$-opioid receptors exhibit opposing alterations of emotional responses. Nat Genet 25:195-200

Fink M, Simeon J, Itil TM, Freedman AM (1970): Clinical antidepressant activity of cyclazocine - a narcotic antagonist. Clin Pharmac Ther 11:41-48 
Hollister LE, Johnson K, Boukhabza D, Gillespie HK (1981): Aversive effects of naltrexone in subjects not dependent on opiates. Drug Alcohol Depend 8:37-41

Hong EJ, Rice KC, Calderon S, Woods JH, Traynor JR (1998): Convulsive behavior of nonpeptide $\delta$-opioid ligands: Comparison of SNC80 and BW373U86 in mice. Analgesia 3:269-276

Houshyar H (2000): Chronic morphine treatment and hypothalamic-pituitary-adrenal axis activity in rats(dissertation). Ann Arbor, MI, University of Michigan

Inturrisi CE, Alexopoulos G, Lipman R, Foley K, Rossier J (1982): $\beta$-Endorphin immunoreactivity in the plasma of psychiatric patients receiving electroconvulsive treatment. Ann N Y Acad Sci 398:413-423

Kita A, Imano K, Seto Y, Yakuo I, Deguchi T, Nakamura H (1997): Antinociceptive and antidepressant-like profiles of BL-2401, a novel enkephalinase inhibitor, in mice and rats. Jpn J Pharmacol 75:337-346

Kline NS, Li CH, Lehmann HE, Lajtha A, Laski E, Cooper T (1977): $\beta$-Endorphin induced changes in schizophrenic and depressed patients. Arch Gen Psychiat 34:1111-1113

Ko M-C, Tuchman JE, Johnson MD, Wiesenauer K, Woods $\mathrm{JH}$ (2000): Local administration of mu or kappa opioid agonists attenuates capsaicin-induced thermal hyperalgesia via peripheral opioid receptors in rats. Psychopharmacol 148:180-185
Maj J (1980): Studies on the action of antidepressant drugs of second generation. Pol J Pharmacol Pharm 32:437-449

Negus SS, Gatch MB, Mello NK, Zhang X, Rice KC (1998): Behavioral effects of the delta-selective opioid agonist SNC80 and related compounds in rhesus monkeys. J Pharmacol Exp Ther 286:362-375

Porsolt RD, Le Pichon M, Jalfre M (1977): Depression: a new animal model sensitive to antidepressant treatments. Nature 266:730-732

Reneric J-P, Lucki I (1998): Antidepressant behavioral effects by dual inhibition of monoamine reuptake in the rat forced swimming test. Psychopharmac 136:190-197

Samanin R, Jori A, Bernasconi S, Morpugo E, Garattini S (1977): Biochemical and pharmacological studies on amineptine (S 1694) and (+)-amphetamine in the rat. J Pharm Pharmac 29:555-558

Spina L, Longoni R, Mulas A, Chang K-J, Di Chiara G (1998): Dopamine-dependent behavioural stimulation by nonpeptide delta opioids BW373U86 and SNC80: 1. Locomotion, rearing and stereotypies in intact rats. Behav Pharmacol 9:1-8

Tejedor-Real P, Mico JA, Smadja C, Maldonado R, Roques BP, Gilbert-Rahola J (1998): Involvement of $\delta$-opioid receptors in the effects induced by endogenous enkephalins on learned helplessness model. Eur J Pharmacol 354:1-7 